\title{
The Impact of Coronavirus (COVID-19) on Higher Education Case Study Private Universities in Mogadishu, Somalia
}

\author{
Mohamed Hassan Mohamed', Shukri Abdulkadir Ahmed'2, Ahmed Mohamud Hussein', \\ Ahmed Sheikh Ali Ahmed'2, Ismail Ibrahim Mohamed², Abdulrahman M. Sheikh ${ }^{3}$ \\ ${ }^{1}$ Public and Environmental Health, Somali International University, Mogadishu, Somalia \\ ${ }^{2}$ Somali International University, Mogadishu, Somalia \\ ${ }^{3}$ Faculty of Heath Science, Somali International University, Mogadishu, Somalia \\ Email: tacshiir@gmail.com, shukriabdulkadir017@gmail.com, hamuudiph15@gmail.com, saabir.010@gmail.com, \\ ismailjaawiye@gmail.com, abdulrahmanbilaal@gmail.com
}

How to cite this paper: Mohamed, M. H., Ahmed, S. A., Hussein, A. M., Ahmed, A. S. A., Mohamed, I. I., \& Sheikh, A. M. (2020). The Impact of Coronavirus (COVID-19) on Higher Education Case Study Private Universities in Mogadishu, Somalia. Creative Education, 11, 2249-2261.

https://doi.org/10.4236/ce.2020.1111165

Received: September 5, 2020

Accepted: November 10, 2020

Published: November 13, 2020

Copyright $\odot 2020$ by author(s) and Scientific Research Publishing Inc. This work is licensed under the Creative Commons Attribution International License (CC BY 4.0).

http://creativecommons.org/licenses/by/4.0/

\begin{abstract}
Background of this paper hence distinguishes the high-influence practice principles of online progressed instruction and gives a logical examination to partners at schools to think driving on the internet preparing in relative conditions. Appraisal is probably going the foremost moving idea to be adjusted to the present new instructive framework, and various colleges are worried about the way to affect a right assessment of understudies, aptitudes and knowledge. The principle target of this investigation is to look at the effect of COVID-19 on instruction Mogadishu-Somalia. The methodology of this examination was utilized elucidating inspecting and was directed on advanced education that lives in Mogadishu Somalia. We've done a study for 15 days, thanks to time requirements: we began to in more than 200 respondents. The results of this examination are that the most scholastic foundations were shut 28 (56\%) yet some scholarly establishments 45 (22.5\%) had said "our organization is incompletely open, yet there are significant interruptions", while 27 (13.5\%) were said "our foundation is open in fact, no unique measures found out for COVID-19." The foremost respondents 126 (66.7\%) were utilized zoom meeting, 40 (21.2\%), they utilized Google study hall. The foremost guardians said yes as typical 79 (73\%) when asked guardians, "Dear guardians; Are you completing routine exercises with regard to COVID-19." Many difficulties of COVID-19 are less conversation of teachers and understudies about the course. The cycle of the Internet learning doesn't permit understudies to urge more clarification. The treats of this condition are monetary issues since you've got to urge web information to urge to your
\end{abstract}


organization to get access E-learning and Meeting meetings, then forth. Conclusion For the understudies, the foremost quick effect has normally been that the impermanent end of up close and private instructing at an advanced education foundation has left them, especially students and therefore, the individuals who are getting to complete upper optional and check out to enter advanced education, during a totally new circumstance, without a far away from of how long it'll keep going, prompt effects on a day life, costs caused and money related weights and, obviously, learning coherence and global portability.

\section{Keywords}

Impact, COVID-19, Higher Education, Privet University

\section{Introduction}

The COVID-19 pandemic episode disturbed life around the globe in 2020. As in some other division, the COVID-19 pandemic influenced trained from multiple points of view (Gonzalez et al., 2020). Government's choices have followed the shared objective of decreasing the spread of COVID by lessening social contact, with an immediate impact in numerous nations staying away from eye to eye educating or potentially tests and limitations on migration (Sintema, 2020) influencing Erasmus understudies. Where potential, classes are being held by means of books and materials taken from school, through different e-learning stages empowering cooperation among instructors and understudies, and, at times, with the assistance of uses shows or web-based media stages. Some training frameworks declared remarkable occasions to all the more likely get ready for this separation learning scenario (Jiao et al., 2020).

Due to the boundless of Corona infection's (Corona virus) in China, following the organization's essentials of "determined educating and learning," most Chinese schools have started internet preparing. During a short period, an outsized number of representatives started to educate before a PC screen, and their understudies got the chance to stay to gathering and take the courses through the on the web (Liu, Bao, Huang, Shi, \& Lu, 2020).

Past China, with the spread of COVID-19 over the planet, as of March 13, 61 countries in Africa, Asia, Europe, the inside East, North America, and South America have announced or realized school and school terminations and an outsized bit of schools have actualized kept closures (Abidah, Hidaayatullaah, Simamora, Fehabutar, \& Mutakinati, 2020).

Appraisal is presumably the foremost provoking idea to be adjusted to the present new instructive framework, and various colleges are worried about the way to affect a right assessment of understudies, aptitudes and knowledge (Douglas, Katikireddi, Taulbut, McKee, \& McCartney, 2020). 
The results of school conclusion possibly reaching bent the furthest limit of the scholarly year, which emerges questions concerning reviewing and valuation of progress that quickly became a critical arrangement challenge. An additional issue is the thanks to decide whether understudies in their last academic year can concentrate satisfactorily or be surveyed decently as far as going to advance education schemes (Toquero, 2020).

Luckily, there are numerous instruments accessible to confront the test of inaccessible learning forced by the COVID-19 pandemic. Hence, the change of substance that has recently instructed up closely and privately is effectively possible. Shockingly, there are other significant errands within the learning cycle, for instance, appraisal or self-governing discovering which will be so far testing without the immediate management of teachers (International Association of Universities, 2020).

Identified with the appraisal cycle, online assessment has gotten one among the foremost concerning ideas within the COVID-19 pandemic flare-up in light of two reasons (UNESCO \& IESALC, 2020). To start out with, educators need to update their on-location assessment so on meet separation assessment prerequisites. Second, it's hazy the way to guarantee that understudies adhere to the rules and do not utilize not-permitted extra material in their assessment tests without the immediate management of teachers (Merkl-Davies, Doris, \& Brennan, 2001).

In Somalia After the underlying fourteen days' conclusion of schools and colleges, the transmission of the infection has taken off, wearing ragged the expectation that understudies would have the option to continue concentrates on grounds. The authority of colleges was constrained to concoct imaginative arrangements that could adjust to the emergency. Colleges depended on elective web-based learning stages, which have gotten one of just approaches to managing these remarkable conditions (Ahmed et al., 2020). This is like advances taken by learning foundations everywhere in the world. The colleges recently depended exclusively on customary physical classes to convey their projects. Hence, web-based learning speaks to another experience and adventure for colleges in Somalia. Be that as it may, most African nations are similarly situated, as web-based instructing is uncommon on the mainland for reasons identified with web network, significant expenses of web information, and destitution (Yusuf, 2020).

Zoom meeting platform is the most commonly used online platform among universities because of its free-use availability. However, the duration of the session lasts for 40 minutes only, requiring classes to restart after this period. This disrupts the smooth running of the lecture and can only be avoided if a subscription of USD 15 per account is paid every month. This would obligate universities to subscribe dozens of accounts for the numbers of classes open and that will cost dearly to the already financially challenged institution (Barre, 2020).

\subsection{Online Teaching Challenges}

The rapid, unprecedented and unprepared for the transition to online teaching 
and learning has brought immense challenges to the Somali higher education institutions, the lecturers and the students. This is similar to their peers across the world, although compounded by the fragile situation of the industry in Somalia. Firstly, universities lacked (and still lack) effective and efficient ICT infrastructure in place that could help to embark on efficient online teaching. Moving to remote learning has been extremely difficult for universities, which already survive on scarce resources. Immediately, they adopted a ubiquitous online conference and chatting apps with a shallow training tutorial for instructors and student population to adapt and use for alternative instruction (Ahmed et al., 2020).

It became apparent that significant numbers of instructors had been conveniently using only whiteboard and textbooks, not laptops. Therefore, many found it difficult adapting to the new technology. This put pressure on respective faculties to provide necessary assistance to these instructors to help uninterrupted delivery of the lectures online (Somalia Education Cluster Note on COVID-19 Preparedness and Response 11, 2020).

\subsection{Impacts on Education}

Going to class each day is that the simplest open arrangement apparatus accessible to support aptitudes. While educational times are regularly fun and should raise social aptitudes and social mindfulness, from a monetary perspective the first purpose of being in school is that it builds a kid's capacity (Bao, 2020).

Indeed, even an almost brief timeframe in school does this; even a comparatively brief time of missed school will have ramifications for aptitude development. In any case, would we be ready to appraise what extent the COVID-19 interference will influence learning? Conditionally, as we are during another world; yet we'll utilize different examinations to encourage an invitation for magnitude (Wang et al., 2020).

\subsection{Impact on Community and Family}

We can perceive at least two channels through which the COVID-19 pandemic is apparently getting the chance to animate changing acknowledged practices and wants. One is in the kindness of organizations. Various associations are directly emerging to be certainly more aware of the childcare needs of their agents and respond by rapidly accepting more versatile work schedules and managing from home alternatives (Zhang \& Ma, 2020).

Through learning by doing and evolving standards, a number of these progressions are likely to demonstrate industrious. Therefore, in numerous spots moms and fathers an equivalent will devour adaptability in fulfilling the joined needs of getting a vocation and running a family. Since immediately ladies are more presented to those contending requests, they continue to be to profit lopsidedly (Wang, Zhang, Zhao, Zhang, \& Jiang, 2020).

A subsequent channel goes through normal practices and good examples in 
singular families. While as a rule mom will eat up an outsized portion of the extra childcare (and self-teaching) during the emergency, there'll even be a sizeable a part of families where good examples are going to be reversed (Ahmed, Allaf, \& Elghazaly, 2020).

\section{General Objective of the Study}

The main objective of this study is to assess the impact of Corona virus (COVID 19) on higher education case study private Universities in Mogadishu, Somalia.

\section{Specific objectives:}

To analyze the impact of coronavirus (COVID-19) on higher education.

$>$ To determine socio demographic effect of COVID-19 on higher education.

\section{Significant of the Study}

They are profiting by all the people especially academics such as senior members of the university, faculty, students, parents., profiting all the network who furnish them with data impact of COVID-19 on training. There are additionally numerous understudies who wish to expound on the COVID-19 and that they likewise get helpful data about their concern. We've planned this exploration to profit the Somalia public.

\section{Methods \& Materials}

\subsection{Research Design}

This study was descriptive cross-sectional study design. Cross-sectional studies are use questionnaires for data collection with the view of generalizing from a sample to a population.

\subsection{Study Area and Target Population}

The study subjects were people living in the capital city of Somalia Mogadishu, Mogadishu which is the capital city of Somalia and located in Benadir region, the Benadir has seventeen districts. This research was undertaken in Banadir region the study was conducted on higher education who are living in Mogadishu Somalia. We have carried out a survey for 15 days, Due to time constraints; we set out to more than two hundred respondents.

\subsection{Sampling Procedure}

A sample of 200 respondents was purposively selected from three hundred respondents including parents, students, lectures, and administration.

\subsection{Data Collection}

The research was collected primary data through the application of questionnaire used to collect the primary data. The data was collected 15 days during 13th to 29th Jun 2020. 


\subsection{Data Analysis}

Data collected was compiled and analyzed using the SPSS version 21.

\subsection{Ethical Considerations}

The written ethical approval and clearance were obtained from research ethics committee in Somali International University (SIU). Totally the participation is voluntary. Participants were not forced to participate in the study. Even those who initially accepted to participate were free to withdraw in the course of the study if they did not wish to continue.

Table 1 showed that the majority of respondents 171 (85.5\%) were male, while 29 (14.5\%) were female respectively. Also, the majority of respondent 140 (70\%) were age between 18 - 25 years, 48 (24\%) Were aged between 26 - 35 years, 6 (3\%) were aged between 36 - 45 years, while $6(3 \%)$ were aged 46 and above years respectively. the most respondents 152 (76\%) have bachelor level, 32 (16\%) who were the most vulnerable groups in the education system which had impact of COVID-19.

Table 2 showed that the most respondents 44 (22\%) were Deputy head of institution (vice president ...) while 2 ( $1 \%$ ) were others (other groups not mentioned in the list) also The above table showed that the most academic institutions have been closed 28 (56\%) but some academic institutions 45 (22.5\%) had said "our institution is partially open, but there are major disruptions" while 27 (13.5\%) were said "Our institution is open as usual, no special measures in place for COVID-19”.

Table 1. Variables associated with socio-demographic characteristics.

\begin{tabular}{ccc}
\hline Variable & Frequency & percentages \\
\hline Gender & & 14.5 \\
Female & 29 & 85.5 \\
Male & 171 & 100 \\
Total & 200 & percentages \\
Age of the Respondent & Frequency & 70 \\
$18-25$ years & 140 & 24 \\
26 - 35 years & 48 & 3 \\
36 - 45 years & 6 & 3 \\
46 years and above & 6 & 100 \\
Total & 200 & percentages \\
Educational level of the Respondent & $\underline{\text { Frequency }}$ & 76 \\
Bachelor level & 152 & 16 \\
Master degree & 32 & 5 \\
PHD Level & 10 & 3 \\
Secondary & 6 & 100 \\
Total & 200 & 5 \\
\hline & & 36 \\
\hline
\end{tabular}


Table 2. Variables associated with academic sector according to the impact of COVID-19.

\begin{tabular}{|c|c|c|}
\hline position of respondents to the survey & $\underline{\text { frequency }}$ & $\underline{\text { Percentage }}$ \\
\hline Head of institution \President, rector and vice president) & 5 & 2.5 \\
\hline Deputy head of institution (vice president...) & 44 & 22 \\
\hline Registrar & 30 & 15 \\
\hline Dean & 24 & 12 \\
\hline Head of department & 29 & 14.5 \\
\hline Faculty member & 35 & 17.5 \\
\hline Lecturer & 31 & 15.5 \\
\hline Others & 2 & 1 \\
\hline Total & 200 & 100 \\
\hline academic institution & Frequency & Percentage \\
\hline $\begin{array}{l}\text { Our institution is open as usual, no special measures in } \\
\text { place for COVID-19 }\end{array}$ & 27 & 13.5 \\
\hline $\begin{array}{l}\text { Our institution is open as usual, but containment measures } \\
\text { have been put in place to avoid spread of COVID-19 }\end{array}$ & 30 & 15 \\
\hline Our institution is partially open, but there are major disruptions & 45 & 22.5 \\
\hline All campus activities have stopped completely & 98 & 49 \\
\hline Total & 200 & 100 \\
\hline $\begin{array}{l}\text { Did you have facilities which easily communicate with students } \\
\text { (and staff) for updates and information? }\end{array}$ & frequency & Percentage \\
\hline Yes & 189 & 94.5 \\
\hline No & 11 & 5.5 \\
\hline Total & 200 & 100 \\
\hline $\begin{array}{l}\text { If you respond YES in the above question; } \\
\text { which program did you use? }\end{array}$ & Frequency & Percentage \\
\hline Zoom & 126 & 66.7 \\
\hline Google class room & 40 & 21.2 \\
\hline Meet Google & 17 & 9 \\
\hline Others & 6 & 3.2 \\
\hline Total & 189 & 100 \\
\hline $\begin{array}{l}\text { If you had already had a partnership with another Institution; } \\
\text { Has COVID-19 affected your partnerships? }\end{array}$ & Frequency & Percentage \\
\hline Yes & 168 & 84 \\
\hline No & 32 & 16 \\
\hline Total & 200 & 100 \\
\hline If Yes; How COVID-19 affected your partnerships? & Frequency & Percentage \\
\hline It weakened the partnership & 90 & 54 \\
\hline $\begin{array}{l}\text { It strengthened them; we coordinated our efforts to } \\
\text { respond to COVID-19 }\end{array}$ & 30 & 17.5 \\
\hline $\begin{array}{l}\text { It created new opportunities with Partner institutions } \\
\text { (shared resources, etc.) }\end{array}$ & 48 & 28.5 \\
\hline
\end{tabular}




\section{Continued}

\begin{tabular}{|c|c|c|}
\hline Total & 168 & 100 \\
\hline \multicolumn{3}{|l|}{$\begin{array}{l}\text { How COVID-19 affected teaching and learning? } \\
\text { (Please select only one) }\end{array}$} \\
\hline It is not affected & 4 & 2 \\
\hline Classroom teaching has been replaced by E-learning & 110 & 55 \\
\hline $\begin{array}{l}\text { Most activities are currently suspended but the institution is work } \\
\text { on developing solutions to continue teaching and learning, } \\
\text { through digital or self-study means }\end{array}$ & 57 & 28.5 \\
\hline Teaching has been cancelled & 29 & 14.5 \\
\hline Total & 200 & 100 \\
\hline $\begin{array}{l}\text { Do you expect you would be able to carry out exams as } \\
\text { planned for this semester? (Please select one) }\end{array}$ & Frequency & Percentage \\
\hline Yes, as usual & 96 & 48 \\
\hline Yes, but through new measures & 84 & 42 \\
\hline Yes, but only in part, some will be postponed & 9 & 4.5 \\
\hline No, the majority of exams are at risk of being postponed & 4 & 2 \\
\hline No, all exams are on hold & 5 & 2.5 \\
\hline don't know & 2 & 1 \\
\hline Total & 200 & 100 \\
\hline Did your institution face challenges during online exams? & Frequency & Percentage \\
\hline Yes & 171 & 85.5 \\
\hline No & 27 & 13.5 \\
\hline Don’t know & 2 & 1 \\
\hline Total & 200 & 100 \\
\hline $\begin{array}{l}\text { if yes, are there strategies being discussed to } \\
\text { address the above issue of exams? }\end{array}$ & Frequency & Percentage \\
\hline Yes & 130 & 76 \\
\hline No & 41 & 24 \\
\hline Total & 171 & 100 \\
\hline
\end{tabular}

Table 2 showed that the most respondents 189 (94.5\%) were said yes when asked "Did you make facilities which easily communicate with students (and staff) for updates and information?" while 11 (5.5\%) were said no respectively. the most respondents 126 (66.7\%) were used zoom meeting, 40 (21.2\%) they used Google class room while 9 (11\%) were used meeting Google and 6 (3.2\%)said no 0 they used another method of E-learning respectively. Also, the most respondents 123 (77\%) were said yes when asked "Do you believe COVID-19 will affect enrollments for the new academic year?" while 61.5 (38.5\%) were said no respectively. the most respondents 123 (77\%) were said yes when asked "did any members of your senior management and lectures been infected by COVID-19?" while 61.5 (38.5\%) were said no respectively, the most respondents 168 (84\%) said that COVID-19 had affected partnership with another academic institution while 32 (16\%) were said that COVID-19 did not affect their partnerships.

Table 3 appeared that the most parents said yes as normal 79 (73\%) when asked parents "Dear parents; Are you carrying out daily activities in the context 
M. H. Mohamed et al.

Table 3. variables related impact of COVID-19 on community (students and parents).

\begin{tabular}{|c|c|c|}
\hline As student do you believe that COVID-19 had affected you? & Frequency & Percentage \\
\hline Yes & 184 & 92 \\
\hline No & 10 & 5 \\
\hline Don’t know & 6 & 3 \\
\hline Total & 200 & 100 \\
\hline $\begin{array}{l}\text { Do you believe that there is difference between access to } \\
\text { classroom and temporary cessation of classroom activity? }\end{array}$ & Frequency & Percentage \\
\hline Yes & 194 & 97 \\
\hline No & 6 & 3 \\
\hline Total & 200 & 100 \\
\hline $\begin{array}{l}\text { Did you face challenges regarding technology? } \\
\text { (Internet, access SMART Phones or Laptops)? }\end{array}$ & Frequency & Percentage \\
\hline Yes & 134 & 67 \\
\hline No & 66 & 33 \\
\hline Total & 200 & 100 \\
\hline $\begin{array}{l}\text { Did you experience anxiety and depression with the regarding } \\
\text { of using these technologies during COVID-19 crisis? }\end{array}$ & Frequency & Percentage \\
\hline Yes & 162 & 81 \\
\hline No & 30 & 15 \\
\hline Don't know & 8 & 4 \\
\hline Total & 200 & 100 \\
\hline $\begin{array}{l}\text { How COVID-19 has impacted on community (Parents)? } \\
\text { (Please select only one) }\end{array}$ & Frequency & Percentage \\
\hline It has not affected it & 40 & 20 \\
\hline $\begin{array}{l}\text { It has increased conflict between parents and students } \\
\text { while students their base became in the Home teaching }\end{array}$ & 66 & 33 \\
\hline It has decreased parent's income & 90 & 45 \\
\hline Don't know & 4 & 2 \\
\hline Total & 200 & 100 \\
\hline $\begin{array}{l}\text { Dear parents; Are you carrying out daily activities } \\
\text { in the context of COVID-19? }\end{array}$ & Frequency & Percentage \\
\hline Yes as normal & 79 & 73 \\
\hline No its effected by COVID 19 & 30 & 27 \\
\hline Total & 109 & 100 \\
\hline Do you believe that COVID-19 will last a long time? & Frequency & Percentage \\
\hline Yes & 168 & 84 \\
\hline No & 32 & 16 \\
\hline Total & 200 & 100 \\
\hline
\end{tabular}


of COVID-19?" while 30 (27\%) said no it's effected by COVID-19. While they most mentioned that the most participants $168(84 \%)$ replied yes when asked" Do you believe that COVID-19 will last a long time? "While also 32 (16\%) said no. Also, when asked students if they believe that there is difference between access to classroom and temporary cessation of classroom activity and they replied 194 (97\%) yes. By the way students had faced challenges regarding technology? (Internet, access SMART Phones or Laptops) and they mentioned yes 134 (67\%) while remained said No 66 (33\%). Also, COVID-19 had impact on Parent's Income when asked how COVID-19 effected Parent's income and they said 90 (45\%) had decreased parent's income due to extra needs from Students.

\section{Discussion}

\section{Qualitative analysis of respondents:}

Dear Participant; as you would like to think, what is the significant test and dangers that your scholarly foundation has placed considering the COVID19?

Most of respondents replied when asked this Question mentioned above as following "The major challenges of COVID-19 are less discussion of lecturer and students about the course. The process of online learning does not allow students to get more explanation. The treats of this condition are financial problem because you need to buy internet data to access your network to get access E-learning and Meeting sessions etc."

Another respondent referenced the followings words: "we live within the midst of what's possibly one of the simplest dangers throughout our life to worldwide training, huge instructive emergency. As of walk 28, 2020 the COVID-19 pandemic is making quite 1.6 billion kids and youth be out of faculty in 161 nations". For far and away most of our Academic which will endure COVID-19 most will probably See decreases in income and increments in costs. I will be able to share three forecasts: 1) Mixed learning will Dramatically Increase. 2) Online Education is going to be a key Priority at the establishment. 3) Existing and potential Partnership are going to be Rethought.

Self-study/instruction: I feel it's the experience time to urge more examination ways like knowing e-separation learning. Also, it relies upon you manage the value of and your cash to contemplate everything whenever in wherever on the earth. We can recognize a minimum of two channels through which the COVID-19 pandemic is apparently getting the chance to animate changing acknowledged practices and wants. One is some help of supervisors. Various associations are right now emerging to be irrefutably more aware of the childcare needs of their delegates and respond by rapidly accepting more versatile work schedules and managing from home other options (Zhang \& Ma, 2020). Through learning by doing and evolving standards, some of these progressions are probably going to demonstrate steady. Therefore, in numerous spots moms and fathers the same will pick up adaptability in satisfying the joined needs of getting a profession and running a family. Since at present ladies are more pre- 
sented to those contending requests, they remain to benefit excessively (Wang, Zhang, Zhao, Zhang, \& Jiang, 2020).

\section{Conclusion}

\section{1) Higher Education Institutions}

Advanced education foundations appear to be evident that each one through the planet, the transitory suspension of the attention to eye exercises of higher education institutions (HEIs) has been a big disrupt or of their working. The effect of this interruption is profoundly factor and depends, right off the bat, on their capacity to remain dynamic in their scholastic exercises, and furthermore, on their monetary maintainability. The endeavors made to stay encouraging courses in virtual mode are prominent everywhere the place and, given the absence of involvement in comparative circumstances before, the exchange has not been simple. Higher education institutions (HEIs) additionally may need adequately developed virtual training frameworks and, even within the most ideal situation, it's hard to feel that they will be scaled-up to the elemental measurements without the mediation of outer specialized backings, as an example, video workers, for instance. To place it plainly, it's one thing to possess the essential mechanical and specialized framework to assist virtual courses for a generally critical level of graduate understudies.

\section{2) On the Demand Side}

What might be compared to $1 / 4$ or more, almost certainly, there'll be a decrease popular for the nonce, and a spike within the following scholarly year when expenses are nonexistent (as in Argentina) or truly reasonable. For the nonce, there'll be various understudies who will not re-visitation of study halls and whose rate is tough to measure. Within us, it's been determined, from a summary of undergrad students 20 , that one in six understudies will not return to campus when face-to-face activities are resumed, yet additionally that four out of ten will keep taking separation advanced education courses. The reasons for transient withdrawal are different. The primary and most elementary are going to be of monetary nature, since the exit from the well-being emergency and its money related ramifications will cause higher joblessness rates and various families are going to be ruined. There are numerous purposes behind the transient decrease wanted for advanced education. The primary and most elementary are going to be monetary, since the exit from the well-being emergency and its money related results will produce higher joblessness rates and various families will get more unfortunate.

\section{Recommendation}

\section{Policy considerations for private universities:}

1) To relieve effects of Pandemics; all the universities should endeavor to assign an extent of their thin assets for putting resources into Ed tech (for example in learning the executive's frameworks). These are fundamental within the 
computerized time, and will encourage instructing and learning in corresponding with the traditional nearby educating. Such mediation will likewise offer opportunities to the tons of potential understudies who can't attend nearby classes for a few reasons and would improve the degree of readiness for questionable conditions and circumstances which could be no COVID19.

2) Private Universities should offer comment the uprightness of the tests through stopping the escape clauses that developed within the new online frameworks. On the off chance that test pride is being mentioned, colleges need to consider deferring end of the year tests and taking tests at grounds or thinking other potential and suitable other options.

3) Internet specialist co-ops should help college understudies in their part by giving minimal effort web information under this condition to assist remember the oppressed understudies for the remote learning.

4) In request to ease colleges' complete reliance on researcher populace educational expenses, the federal of Somalia needs to give endowments to the universities and not limit its subsidizing just to the state funded college. Moreover, colleges got to appear for various wellsprings of dollars beside understudy charges to stay up their activities.

5) Universities should trap the open door gave the guide of the pandemic in expanding the extent of their activity to supply their projects online to possible understudies in various areas of Somalia and therefore, the spot who aren't capable attend classes for differing reasons. Also, Universities organize to share encounters and considerations on amazing practice for online acing.

\section{Conflicts of Interest}

The authors declare no conflicts of interest regarding the publication of this paper.

\section{References}

Abidah, A., Hidaayatullaah, H. N., Simamora, R. M., Fehabutar, D., \& Mutakinati, L. (2020). The Impact of COVID-19 to Indonesian Education and Its Relation to the Philosophy of "Merdeka Belajar." Studies in Philosophy of Science and Education, 1, 38-49. https://doi.org/10.46627/sipose.v1i1.9

Ahmed, H., Allaf, M., \& Elghazaly, H. (2020). COVID-19 and Medical Education. The Lancet Infectious Diseases, 20, 777-778. https://doi.org/10.1016/S1473-3099(20)30226-7

Ahmed, M. A. M., Fodjo, J. N. S., Gele, A. A., Farah, A. A., Osman, S., Guled, I. A., Ali, A. M., \& Colebunders, R. (2020). Covid-19 in Somalia: Adherence to Preventive Measures and Evolution of the Disease Burden. Pathogens, 9, 1-11.

https://doi.org/10.3390/pathogens9090735

Bao, W. (2020). COVID-19 and Online Teaching in Higher Education: A Case Study of Peking University. Human Behavior and Emerging Technologies, 2, 113-115. https://doi.org/10.1002/hbe2.191

Barre, A. G. (2020). Somalia Education Sector COVID-19 Response Plan. https://planipolis.iiep.unesco.org/en/2020/somalia-education-sector-covid-19-response 
-plan-6926

Douglas, M., Katikireddi, S. V., Taulbut, M., McKee, M., \& McCartney, G. (2020). Mitigating the Wider Health Effects of Covid-19 Pandemic Response. The BMJ, 369, m1557. https://doi.org/10.1136/bmj.m1557

Gonzalez, T., de la Rubia, M. A., Hincz, K. P., Comas-Lopez, M., Subirats, L., Fort, S., \& Sacha, G. M. (2020). Influence of COVID-19 Confinement in Students Performance in Higher Education (pp. 1-25). http://arxiv.org/abs/2004.09545 https://doi.org/10.35542/osf.io/9zuac

International Association of Universities (2020). Impacts of Covid-19 on HE Worldwide-Resources for Universities and HEIs Compiled by IAU-Updated 24 April 2020 (pp. 1-27).

Jiao, W. Y., Wang, L. N., Liu, J., Fang, S. F., Jiao, F. Y., Pettoello-Mantovani, M., \& Somekh, E. (2020). Behavioral and Emotional Disorders in Children during the COVID-19 Epidemic. Journal of Pediatrics, 221, 264-266.e1. https://doi.org/10.1016/j.jpeds.2020.03.013

Liu, J. J., Bao, Y., Huang, X., Shi, J., \& Lu, L. (2020). Mental Health Considerations for Children Quarantined Because of COVID-19. The Lancet Child and Adolescent Health, 4, 347-349. https://doi.org/10.1016/S2352-4642(20)30096-1

Merkl-Davies, D. M., \& Brennan, N. (2001). Provided by the Author(s) and University College Dublin Library in Accordance with Publisher Policies. Please cite the published version when available. Discretionary disclosure strategies in corporate narratives: incremental information or impression ma. The Irish Journal of Psychology, 32, 4-13.

Sintema, E. J. (2020). Effect of COVID-19 on the Performance of Grade 12 Students: Implications for STEM Education. Eurasia Journal of Mathematics, Science and Technology Education, 16, 1-6. https://doi.org/10.29333/ejmste/7893

Somalia Education Cluster Note on COVID-19 Preparedness and Response 11 (2020).

Toquero, C. M. (2020). Challenges and Opportunities for Higher Education amid the COVID-19 Pandemic: The Philippine Context. Pedagogical Research, 5, em0063. https://doi.org/10.29333/pr/7947

UNESCO \& IESALC (2020). COVID-19 and Higher Education: Today and Tomorrow. Impact Analysis, Policy Responses and Recommendations. Iesalc, April, No. 9, 1-46. https://bit.ly/34TOSvu

Wang, C., Pan, R., Wan, X., Tan, Y., Xu, L., Ho, C. S., \& Ho, R. C. (2020). Immediate Psychological Responses and Associated Factors during the Initial Stage of the 2019 Coronavirus Disease (COVID-19) Epidemic among the General Population in China. International Journal of Environmental Research and Public Health, 17, 1729. https://doi.org/10.3390/ijerph17051729

Wang, G., Zhang, Y., Zhao, J., Zhang, J., \& Jiang, F. (2020). Mitigate the Effects of Home Confinement on Children during the COVID-19 Outbreak. The Lancet, 395, 945-947. https://doi.org/10.1016/S0140-6736(20)30547-X

Yusuf, F. I. (2020). Governance Brief 08 Examining the Impact of COVID-19 on Higher Education in Mogadishu.

Zhang, Y., \& Ma, Z. F. (2020). Impact of the COVID-19 Pandemic on Mental Health and Quality of Life among Local Residents in Liaoning Province, China: A Cross-Sectional Study. International Journal of Environmental Research and Public Health, 17, 2381. https://doi.org/10.3390/ijerph17072381 